\title{
Intratumoral treatment of one tumor lesion with LTX-315 induces complete tumor regression and long-term specific protective immune responses in a metastatic rodent tumor model
}

\author{
Öystein Rekdal ${ }^{1}$, Janne Nestvold ${ }^{2}$, Meng Yu Wang ${ }^{3}$, Ketil A Camilio ${ }^{4}$, Baldur Sveinbjörnsson ${ }^{4^{*}}$, Gunnar Kvalheim ${ }^{3}$
}

From Society for Immunotherapy of Cancer 29th Annual Meeting

National Harbor, MD, USA. 6-9 November 2014

Host defense peptides are naturally occurring peptides that have an important function in innate immune responses in almost every life form. Recently it has been documented that several host defense peptides have anticancer activity. Based on a naturally occurring host defense peptide, we have do novo designed the short chemically modified peptide LTX-315. We have demonstrated that LTX-315 induces an immunogenic type of cell death with subsequent release of danger signals (e.g. HMBG1, ATP and Cytochrome $C$ ) and tumor associated antigens (TAA's). In addition LTX-315 also has the ability to directly modulate immune-responses.

In a novel rat mescenhymal sarcoma model (rTMSC) we demonstrate that LTX-315 induces a complete tumor regression by intratumoral (i.t.) injection. Studies on treated tumor tissue confirmed massive necrosis and infiltration of immune cells. Successfully treated animals were protected against re-challenge with the tumor cell type treated, but not against other types of tumor cells. Moreover, tumor resistance could be adoptively transferred by spleen cells from LTX-315-treated animals. The resistance was abrogated by depletion of T-lymphocytes.

To clarify whether intratumoral injection of LTX-315 in one tumor lesion can have an effect on metastatic disease, intraperitoneal tumor and two subcutaneous tumors were established in the animals. Thereafter, LTX-315 was injected into one of the subcutaneous lesion and tumor growth assessed by living imaging. The results showed that LTX-315 eradicated all three lesions and the animal went into durable complete remission.

\footnotetext{
${ }^{4}$ Molecular Inflamamtion Research Group, Inst. Medical Biology, University of Tromsö, Tromsö, Norway

Full list of author information is available at the end of the article
}

We propose that by targeting tumor locally LTX-315 can be used for individualized therapeutic in situ vaccination against cancer.

\section{Authors' details}

${ }^{1}$ Lytixbiopharma, Oslo, Norway, Oslo, Norway. ${ }^{2}$ Dept. of Anatomy, Inst. Basal Medical Sciences, University of Oslo, Oslo, Norway. ${ }^{3}$ Dept of Cellular Therapy, Inst. Cancer Research, The Norwegian Radium Hospital, Oslo, Norway. ${ }^{4}$ Molecular Inflamamtion Research Group, Inst. Medical Biology, University of Tromsö, Tromsö, Norway.

Published: 6 November 2014

\section{doi:10.1186/2051-1426-2-S3-P236}

Cite this article as: Rekdal et al.: Intratumoral treatment of one tumor lesion with LTX-315 induces complete tumor regression and long-term specific protective immune responses in a metastatic rodent tumor model. Journal for ImmunoTherapy of Cancer 2014 2(Suppl 3):P236.

Submit your next manuscript to BioMed Central and take full advantage of:

- Convenient online submission

- Thorough peer review

- No space constraints or color figure charges

- Immediate publication on acceptance

- Inclusion in PubMed, CAS, Scopus and Google Scholar

- Research which is freely available for redistribution 